\title{
EMOSI POSITIF MEMEDIASI PENGARUH ATMOSFER TOKO TERHADAP PEMBELIAN TIDAK TERENCANA
}

\author{
I Putu Widya Artana ${ }^{1}$ \\ Ni Made Asti Aksari ${ }^{2}$ \\ ${ }^{1,2}$ Fakultas Ekonomi dan Bisnis Universitas Udayana (Unud), Bali, Indonesia \\ email: putuwidyaartana@gmail.com
}

\begin{abstract}
ABSTRAK
Pembelian tidak terencana merupakan pembelian yang dilakukan secara mendadak tanpa melalui proses perencanaan. Pembelian tidak terencana dapat disebabkan oleh berbagai faktor, salah satunya adalah rangsangan yang diciptakan melalui atmosfer toko. Pengaturan atmosfer toko yang baik akan menimbulkan emosi positif pada konsumen. Penelitian ini bertujuan untuk mengetahui peran emosi positif dalam memediasi pengaruh atmosfer toko terhadap pembelian tidak terencana pada konsumen Alfamart di Kota Denpasar. Penelitian ini menggunakan 104 orang sebagai sampel dengan menggunakan teknik purposive sampling. Data dalam penelitian ini dikumpulkan melalui kuesioner secara online menggunakan google form. Teknik analisis yang digunakan dalam penelitian ini adalah analisis jalur. Hasil penelitian menunjukkan atmosfer toko mempunyai pengaruh positif dan signfikan terhadap emosi positif, sementara itu atmosfer toko dan emosi positif juga berpengaruh positif dan signifikan terhadap pembelian tidak terencana. Hasil penelitian ini juga menunjukkan bahwa emosi positif mampu memediasi pengaruh atmosfer toko terhadap pembelian tidak terencana.
\end{abstract}

Kata kunci : atmosfer toko, emosi positif, pembelian tidak terencana.

\begin{abstract}
Unplanned purchases are purchases that are made without going through the planning process. Unplanned purchases are caused by various factors, one example is store atmosphere. A good store atmosphere can generate positive emotions on consumers. This study aims to determine the role of positive emotions in mediating the influence of store atmosphere on unplanned purchases in Alfamart Denpasar. This study used 104 people as samples by using purposive sampling technique. Data in this study were collected through online questionnaires using Google form, and analysed using Path analysis. The results show that store atmosphere has significant influence on positive emotions and unplanned purchases. Positive emotions also have significant effect on unplanned purchases. Furthermore, study results also show that positive emotions can mediate the influence of store atmosphere on unplanned purchases.

Keywords: store atmosphere, positive emotions, unplanned purchases.
\end{abstract}




\section{PENDAHULUAN}

Pembelian yang dilakukan secara tidak terencana saat ini semakin banyak ditemui di berbagai tempat berbelanja. Pembelian tidak terencana atau impulse buying sendiri adalah sebuah aktivitas belanja yang dilakukan secara seketika atau mendadak tanpa melalui proses perencanaan. Pembelian tidak terencana merupakan sebuah kesenangan tersendiri bagi konsumen yang merupakan dorongan dari tujuan hedonik. Pembelian tidak terencana adalah keinginan untuk berbelanja dalam diri seseorang yang lebih didasari oleh faktor emosional daripada rasional

Pembelian tidak terencana merupakan penting yang perlu diperhatikan oleh para pebisnis ritel karena pembelian tidak terencana ini adalah salah satu jenis dari perilaku konsumen. Bisnis ritel sendiri bisa diartikan sebagai segala kegitan penjualan atau juga distribusi produk yang dilakukan langsung ke para konsumen atau pengguna akhir yang langsung menggunakan suatu produk. Menurut Ahad et al. (2015) dengan terus meningkatnya hedonisme di kalangan masyarakat dapat menyebabkan terjadinya perilaku pembelian impulsif. Menurut Khorrami \& Esfidani (2015), pembelian tidak terencana dapat terjadi saat konsumen belum menentukan produk yang akan dibeli dan belum mempunyai niat untuk melakukan pembelian saat melakukan aktivitas perbelanjaan. Menurut Hussain \& Ali (2015), suasana sebuah toko khususnya pada toko ritel modern perlu diperhatikan oleh pemasar, agar konsumen dapat berbelanja dengan nyaman sehingga pelanggan betah berlama-lama berada di dalam toko. Semakin panjang waktu yang dipergunakan konsumen di dalam toko, akan dapat menyebabkan meningkatnya kemungkinan konsumen melakukan pembelian implusif (Fam et al., 2015).

Pengaturan suasana atau atmosfer toko yang baik sangat perlu dilakukan khususnya di Indonesia, karena dalam melakukan kegiatan belanja, konsumen di Indonesia selalu berkeinginan untuk dapat melakukannya pada tempat yang nyaman serta dapat dilakukan dengan mudah. Dalam merespon hal tersebut, sekarang ini banyak bermunculan berbagai bentuk bisnis ritel modern seperti shopping centre, supermarket, department store, minimarket, dan lain sebagainya yang hadir dengan suasana gerai yang sangat tertata. Kemunculan berbagai bisnis ritel ini membuat pelaku ritel tradisional harus mampu memutar otak agar dapat bersaing dengan gerai-gerai ritel modern, oleh karena itu saat ini banyak dijumpai berbagai gerai-gerai ritel tradisional seperti warung dan toko dimoderenisasi dengan menambah berbagai fasilitas seperti $A C, C C T V$, serta komputerisasi metode pembayaran. Hal tersebut memang sudah seharusnya dilakukan oleh semua pelaku bisnis ritel agar dapat bersaing dengan bisnis ritel lainnya serta dapat mempertahankan kelangsungan bisnis mereka. Keinginan masyarakat saat ini akan suasana tempat belanja yang nyaman membuat bisnis ritel modern saat ini menjadi salah satu bisnis yang cukup berkembang. Kondisi ini diperkuat dengan perekonomian di Indonesia yang menunjukkan prospek yang baik serta jumlah penduduk Indonesia yang terus meningkat dari waktu ke waktu membuat bisnis ritel di Indonesia menjadi bisnis yang cukup potensial bagi para pelaku bisnis ritel.

Minimarket adalah satu dari sekian bentuk bisnis ritel modern. Minimarket adalah gerai yang menjual berbagai kebutuhan sehari-hari dengan format modern yang lokasinya dekat dengan pemukiman masyarakat sehingga dapat dengan mudah dijangkau yang keberadaannya dapat mengungguli toko-toko tradisional 
Salah satu minimarket yang beroperasi di Indonesia adalah Alfamart. Alfamart adalah sebuah jaringan minimarket di Indonesia yang menjual berbagai produk kebutuhan sehari-hari seperti perlatan mandi, minuman, makanan dan berbagai kebutuhan sehari-hari lainnya yang mana gerai dari Alfamart sudah tersebar di seluruh penjuru Indonesia.

Alfamart dalam menjalankan usaha Minimarket tidak sendiri yang mana Alfamart memiliki banyak pesaing dalam sektor bisnis ini. Salah satu pesaing utama dari Alfamart adalah Indomaret. Indomaret merupakan satu dari sekian jaringan Minimarket terbesar di Indonesia, di mana sampai awal tahun 2019 sudah memiliki lebih dari 16.000 gerai yang tersebar diseluruh Indonesia yang mana jumlah ini lebih banyak dari jumlah gerai Alfamart dan sama-sama menyasar kelas menengah ke bawah. Gerai Alfamart dan Indomaret seringkali berada dengan jarak yang dekat bahkan bersebelahan, hal ini tentunya membuat persaingan antar kedua Minimarket ini sangat ketat pada setiap daerah di Indonesia.

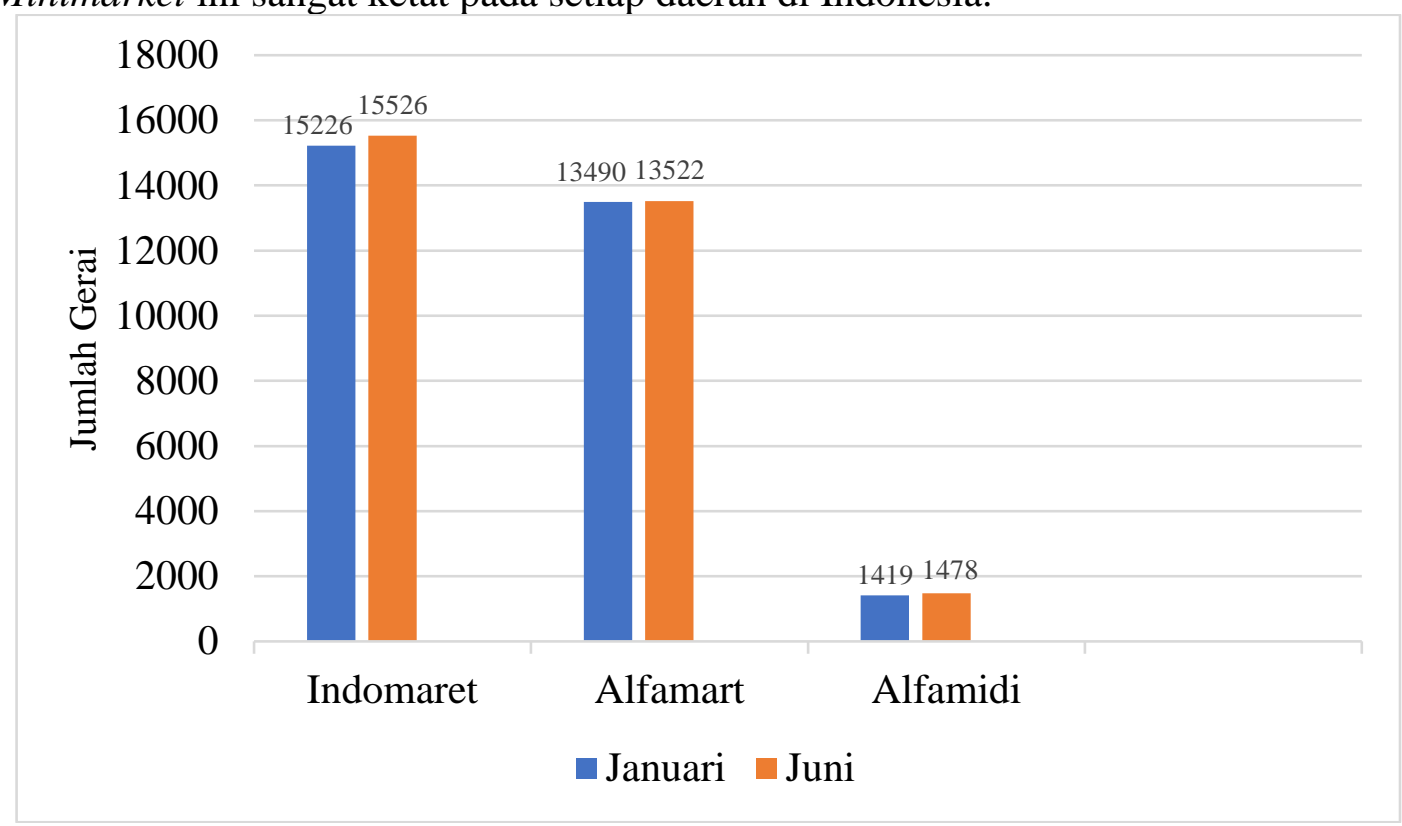

\section{Gambar 1. Perbandingan Jumlah Gerai Minimarket di Indonesia Tahun 2018}

Sumber: Data Diolah, 2019

Persaingan pada bisnis ritel khsusnya Minimarket yang semakin ketat membuat Alfamart satu dari sekian jaringan Minimarket terbesar di Indonesia harus dapat membuat strategi bersaing yang efektif, karena dengan banyaknya pesaing akan membuat konsumen akan mudah pergi jika pelaku bisnsi ritel tidak bisa mengantisipasi. Penataan suasana atau atmosfer gerai yang baik adalah sebuah strategi yang dapat membuat konsumen bersedia menghabiskan waktunya di dalam gerai, sehingga akan memperbesar potensi pembelian tidak terencana dari konsumen (Fam et al., 2015).

Berdasarkan penelitian Utami \& Rastini (2015) pada konsumen Hypermart Mall Bali Galeria, atmosfer toko mempunyai pengaruh yang positif dan signifikan terhadap pembelian tidak terencana, hal ini sejalan dengan penelitian yang dilakukan oleh Jaya \& Suparna (2018) pada konsumen Temaday Store di Denpasar. 
Apabila sebuah tempat belanja dapat menghadirkan atmosfer atau suasana yang baik, maka hal tersebut akan menimbulkan sebuah emosi positif. Emosi positif dapat disebut sebagai proses afektif psikologis yang terdapat dalam pembelian tidak terencana. Emosi positif adalah sebuah rasa senang pada dalam diri yang disebakan oleh lingkungan di sekitar yang kemudian akan mendorong terjadinya pembelian implusif (Kinasih dan Jatra 2018). Emosi positif merupakan keadaan di mana konsumen mempunyai perasaan positif yang timbul dari motivasi di dalam dirinya untuk memuaskan dirinya dengan melakukan tindakan pembelian implusif. Dengan menciptakan emosi yang positif terhadap konsumen pada lingkungan gerai sebagai tempat perbelanjaan akan dapat meningkatkan pembelian implusif yang dilakukan oleh konsumen (Amiri et al., 2015)

Penelitian yang dilakukan oleh Dewi \& Giantari (2015) pada konsumen Matahari Departement Store Denpasar, Dharma \& Kusumadewi (2018) pada konsumen Karakter Kopi Denpasar memperlihatkan bahwa atmosfer toko mempunyai pengaruh positif dan signifikan terhadap emosi positif. Penelitian ini didukung juga oleh penelitian Negara \& Kusumadewi (2018) pada konsumen Hypermart Carrefour di kota Denpasar, Helmefalk \& Hulten (2017) padan konsumen ritel di Swedia yang juga menyatakan bahwa atmosfer toko mempunyai pengaruh positif dan signifikan terhadap emosi positif.

Penelitian Budiharta \& Santika (2015) pada konsumen Matahari Depastement Store Kuta Square memperlihatkan emosi positif berpengaruh positif signifikan terhadap pembelian tidak terencana yang mana hal ini didukung oleh penelitian dari Darmayasa \& Sukaatmadja (2017) pada konsumen Indomaret di Kota Denpasar serta Kinasih \& Jatra (2018) pada konsumen produk fashion Discovery Shopping Mall Kuta yang juga memperlihatkan hasil yang sama. Penelitian yang dilakukan oleh Negara \& Kusumadewi (2018) pada konsumen Hypermart Carrefour di Kota Denpasar, serta Dharma \& Kusumadewi (2018) pada konsumen gerai Karakter Kopi Denpasar, memperoleh hasil bahwa emosi positif dapat memediasi pengaruh atmosfer toko terhadap pembelian tidak terencana. Hal ini sejalan dengan penelitian yang dilakukan Budiharta \& Santika (2015) pada konsumen Matahari Depastement Store Kuta Square yang memperoleh hasil yang sama bahwa emosi positif memediasi pengaruh atmosfer toko terhadap pembelian tidak terencana.

Berdasarkan hasil penelitian yang dilakukan oleh Dewi \& Giantari (2015), Dharma \& Kusumadewi (2018) menyatakan bahwa atmosfer toko mempunyai penagruh positif dan signifikan terhadap emosi positif. Penelitian ini didukung oleh penelitian Helmefalk \& Hulten (2017), serta Negara \& Kusumadewi (2018) yang juga menyatakan bahwa atmosfer toko berpengaruh positif dan signifikan terhadap emosi positif. Berdasarkan hasil penelitian-penelitian sebelumnya, maka hipotesis dalam penelitian ini adalah sebagai berikut:

$\mathrm{H}_{1}$ :Atmosfer toko berpengaruh positif dan signifikan terhadap emosi positif.

Berdasarkan penelitian yang telah dilakukan oleh Utami \& Rastini (2015), Pemayun \& Ekawati (2016), Setiawati \& Sukawati (2017), menyatakan bahwa atmosfer toko mempunayai pengaruh positif dan signifikan terhadap pembelian tidak terencana. Penelitian-penelitian juga didukung oleh penelitian yang dilakukan oleh Jaya \& Suparna (2018), Temaja et al. (2015), di mana juga menyatakan bahwa 
atmosfer toko berpengaruh positif dan signifikan terhadap pembelian tidak terencana Berdasarkan hasil penelitian-penelitian sebelumnya, maka hipotesis dalam penelitian ini adalah sebagai berikut:

$\mathrm{H}_{2}$ :Atmosfer toko berpengaruh positif dan signifikan terhadap pembelian tidak terencana.

Berdasarkan penelitian yang dilakukan Budiharta \& Santika (2015) memperoleh hasil bahwa emosi positif berpengaruh positif signifikan terhadap pembelian tidak terencana yang mana hal ini didukung oleh penelitian yang dilakukan oleh Darmayasa \& Sukaatmadja (2017), Kinasih \& Jatra (2018) yang juga memperlihatkan hasil yang sama bahwa emosi positif berpengaruh positif dan signifikan terhadap pembelian tidak terencana. Berdasarkan hasil penelitianpenelitian sebelumnya, maka hipotesis penelitian dalam penelitian ini adalah sebagai berikut:

$\mathrm{H}_{3}$ : Emosi positif berpengaruh positif dan signifikan terhadap pembelian tidak terencana.

Berdasarkan penelitian yang dilakukan oleh Dewi \& Giantari (2015), Negara \& Kusumadewi (2018), Dharma \& Kusumadewi (2018) menyatakan bahwa emosi positif memediasi pengaruh atmosfer toko terhadap pemebelian tidak terencana. Hal ini sejalan dengan penelitian yang dilakukan Budiharta \& Santika (2015)yang juga menyatakan hal yang sama bahwa emosi positif memediasi pengaruh atmosfer toko terhadap pembelian tidak terencana. Berdasarkan hasil penelitian sebelumnya, maka hipotesis dalam penelitian ini adalah sebagai berikut:

$\mathrm{H}_{4}$ : Emosi positif memediasi pengaruh atmosfer toko terhadap pembelian tidak terenana.

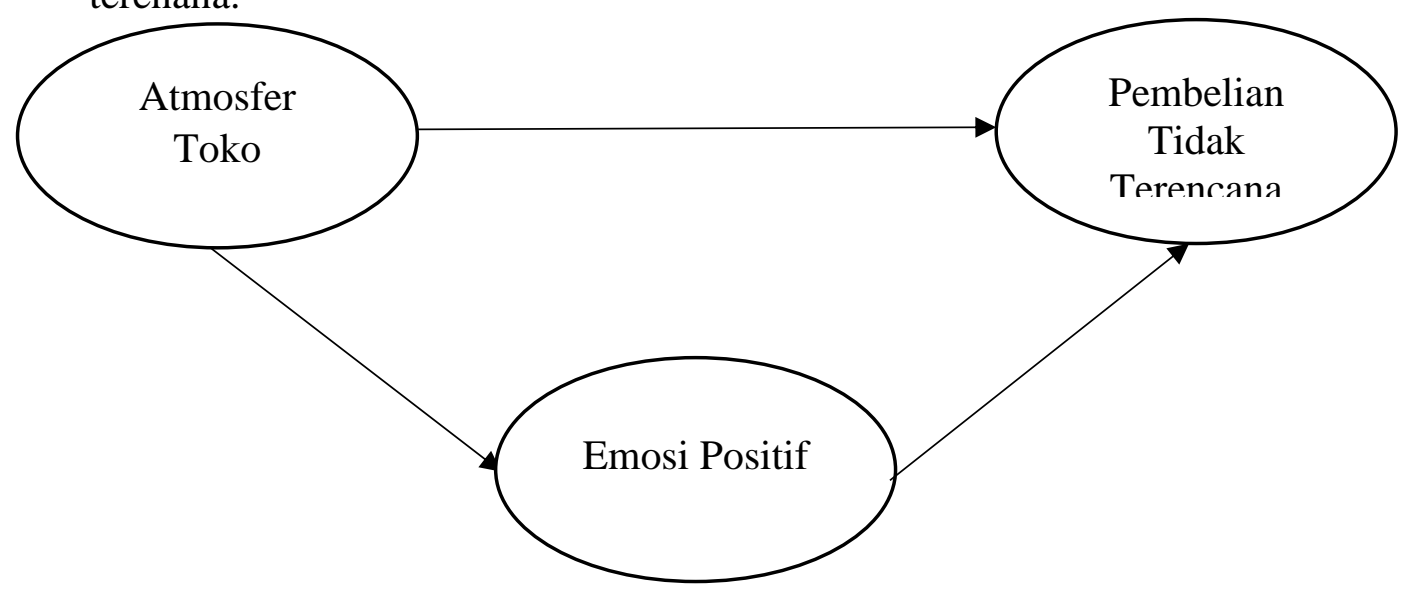

Gambar 2. Kerangka Konseptual

\section{METODE PENELITIAN}

Penelitian ini merupakan penelitian dengan pendekatan kuantitatif asosiatif. Penelitian ini bertujuan untuk mengetahui hubungan antar variabel yang dalam hal ini menjelaskan hubungan variabel bebas yaitu atmosfer toko $(X)$, variabel mediasi yaitu emosi positif (M), dan variabel terikat yaitu pembelian tidak terencana (Y). Penelitian ini dilakukan di seluruh gerai Alfamart yang berada di wilayah Kota Denpasar. Lokasi ini dipilih karena Kota Denpasar adalah kota terbesar yang berada 
di Bali dengan jumlah penduduk terbanyak di Bali yaitu sekitar 788.589 selain itu Kota Denpasar juga mempunyai demografi yang beragam dan rata-rata penghasilan penduduknya yang lebih tinggi dibandingkan dengan beberapa daerah lain di Bali, sehingga membuat potensi pembelian implusif di Kota Denpasar cukup tinggi. Kota Denpasar juga dipilih karena memiliki jumlah gerai Alfamart lebih banyak dibandingkan daerah lain di Bali yaitu 53 gerai dari 358 gerai yang terdapat di seluruh Bali.

Objek dalam penelitian ini adalah pengaruh atmosfer toko terhadap pembelian tidak terencana yang dimediasi oleh emosi positif pada konsumen Alfamart yang berada di Kota Denpasar. Variabel bebas yang terdapat dalam penelitian ini adalah atmosfer toko. Variabel mediasi yang terdapat dalam penelitian ini adalah emosi positif. Variabel terikta yang terdapat dalam penelitian ini adalah pembelian tidak terencana (impulse buying)

Data kualitatif yang terdapat pada penelitian ini adalah berbagai informasi yang diperoleh melalui jurnal, artikel, buku, dan sumber lainnya yang bersifat kualitatif yang mempunyai hubungan dengan penelitian ini. Data kuantitatif yang terdapat pada penelitian ini merupakan data yang berasal dari data kualitatif dari kuesioner yang kemudian diubah menjadi bentuk angka menggunakan metode scorring, selain itu juga terdapat berbagai data kuantitatif lainnya, seperti umur responden dan lain sebagainya. Sumber primer yang terdapat pada penelitian ini adalah data-data yang diperoleh dari responden melalui jawaban yang diberikan dari kuesioner yang diberikan. Sumber sekunder yang terdapat pada penelitian ini adalah data-data yang diperoleh dari penelitian-penelitian sebelumnya yang berbentuk jurnal, data dari buku, kependudukan dan lain sebagainya.

Populasi yang terdapat pada penelitian ini meliputi konsumen Alfamart di Kota Denpasar yang pernah melakukan kegiatan perbelanjaan di gerai Alfamart yang berada di dalam wilayah Kota Denpasar. Penelitian ini menggunakan 104 orang responden sebagai sampel. Pada penelitian ini indikator yang digunakan berjumlah 13, oleh karena itu ukuran sampel yang dapat digunakan berkisar antara 65 - 130 sampel. Teknik pengambilan sampel yang digunakan dalam penelitian ini adalah purposive sampling. Kriteria yang dapat dijadikan sampel dalam penelitian ini adalah sebagai berikut: (1) Bertempat tinggal di Kota Denpasar, (2) Pendidikan terakhir minimal SMA sederajat, (3) Pernah melakukan perbelanjaan secara tidak terencana pada gerai Alfamart di Kota Denpasar dalam kurun waktu 1 bulan terakhir.Data yang terdapat dalam penelitian ini diperoleh melalui kuesioner, di mana kuesioner ini disebarkan kepada responden oleh peneliti seacara online melalui media sosial serta menggunakan bantuan google form.

\section{HASIL DAN PEMBAHASAN}

Karakteristik responden adalah data profil dari responden yang telah mengisi kuesioner, di mana dalam penelitian ini menggunakan teknik purposive sampling sehingga responden yang dapat mengisi kuesioner penelitian ini harus dapat memenuhi syarat-syarat yang telah ditentukan. Penelitian ini menggunakan 100 orang responden, adapun data-data responden yang terdapat dalam penelitian ini 
adalah berupa data-data demografi seperti jenis kelamin, usia, pendidikan terakhir dan pekerjaan.

Tabel 1.

Karakteristik Responden Berdasarkan Jenis Kelamin

\begin{tabular}{cccc}
\hline No & Jenis Kelamin & Jumlah & Persentase (\%) \\
\hline 1 & Perempuan & 57 & 54,8 \\
2 & Laki-Laki & 47 & 45,2 \\
& Total & $\mathbf{1 0 4}$ & $\mathbf{1 0 0}$
\end{tabular}

Sumber: Data Diolah, 2019

Berdasarkan Tabel 1. menunjukkan bahwa dalam penelitian ini jumlah responden perempuan lebih banyak dibandingkan jumlah responden laki-laki, hal ini dapat dilihat pada tabel bahwa responden perempuan berjumlah 57 orang, sementara itu responden laki-laki berjumlah 47 orang.

Tabel 2.

Karakteristik Responden Berdasarkan Usia

\begin{tabular}{cccc}
\hline No & Usia & Jumlah & Persentase (\%) \\
\hline 1 & $17-26$ & 99 & 95,2 \\
2 & $27-36$ & 5 & 4,8 \\
3 & $37-46$ & 0 & 0 \\
4 & $47-56$ & 0 & 0 \\
5 & $57<$ & 0 & 0 \\
& Total & $\mathbf{1 0 4}$ & $\mathbf{1 0 0}$ \\
\hline
\end{tabular}

Sumber: Data Diolah, 2019

Berdasarkan Tabel 2. dapat diketahui bahwa responden pada kuesioner penelitian ini paling banyak berusia 17 - 26 tahun yaitu sebanyak 99 orang responden, sementara responden dengan kelompok usia 27 - 36 tahun dalam kuesioner penelitian ini berjumlah 5 orang.

Tabel 3.

Karakteristik Responden Berdasarkan Pendidikan Terakhir

\begin{tabular}{cccc}
\hline No & Pendidikan Terakhir & Jumlah & Persentasi (\%) \\
\hline 1 & SMA/Sederajat & 78 & 75 \\
2 & Diploma & 3 & 2,9 \\
3 & Sarjana & 22 & 21,2 \\
4 & Pascasarjana & 1 & 1 \\
& Total & $\mathbf{1 0 4}$ & $\mathbf{1 0 0}$ \\
\hline
\end{tabular}

Sumber: Data Diolah, 2019

Berdasarkan Tabel 3. dapat diketahui bahwa dalam penelitian ini responden dengan pendidikan terakhir terbanyak adalah SMA/Sederajat dengan jumlah 78 orang, diurutan kedua adalah sarjana dengan jumlah responden sebanyak 22 orang, diurutan ketiga adalah diploma dengan jumlah responden sebanyak 3 orang, dan yang terkahir adalah pascasarjana dengan jumlah responden sebanyak 1 orang. 
Tabel 4.

Karakteristik Responden Berdasarkan Pekerjaan

\begin{tabular}{cccc}
\hline No & Pekerjaan & Jumlah & Persentase (\%) \\
\hline 1 & Pelajar/Mahasiswa & 83 & 79,8 \\
2 & Pegawai Swasta & 13 & 12,5 \\
3 & PNS & 1 & 1 \\
4 & Wiraswasta & 0 & 0 \\
5 & Lainnya & 7 & 6,7 \\
& Total & $\mathbf{1 0 4}$ & $\mathbf{1 0 0}$ \\
\hline
\end{tabular}

Sumber: Data Diolah, 2019

Berdasarkan Tabel 4. dapat dilihat bahwa dalam penelitian ini responden dengan pekerjaan sebagai pelajar/mahasiswa merupakan jenis responden terbanyak berdasarkan pekerjaan dengan jumlah 83 orang, sementara jumlah responden yang bekerja sebagai pegawai swasta sebanyak 13 orang, PNS 1 orang, dan lainnya berjumlah 7 orang.

Tabel 5.

Hasil Uji Validitas

\begin{tabular}{ccccc}
\hline \multirow{2}{*}{ No } & \multirow{2}{*}{ Variabel } & Item Pernyatan & $\begin{array}{c}\text { Korelasi Item } \\
\text { Total }\end{array}$ & Sig \\
\hline 1 & Atmosfer Toko & $\mathrm{X}_{1}$ & 0,768 & 0,000 \\
& $\mathrm{X}$ & 0,744 & 0,000 \\
& $\mathrm{X}_{3}$ & 0,786 & 0,000 \\
& $\mathrm{X}_{4}$ & 0,669 & 0,000 \\
& $\mathrm{X}_{5}$ & 0,674 & 0,000 \\
& & $\mathrm{X}_{6}$ & 0,765 & 0,000 \\
& Emosi Positif & $\mathrm{M}_{1}$ & 0,775 & 0,000 \\
& & $\mathrm{M}_{2}$ & 0,846 & 0,000 \\
& & $\mathrm{M}_{3}$ & 0,846 & 0,000 \\
& & $\mathrm{M}_{4}$ & 0,763 & 0,000 \\
& & $\mathrm{Y}_{1}$ & 0,833 & 0,000 \\
& & $\mathrm{Y}_{2}$ & 0,766 & 0,000 \\
& Pembelian Tidak & $\mathrm{Y}_{3}$ & 0,870 & 0,000 \\
\hline
\end{tabular}

Sumber: Data Diolah, 2019

Berdasarkan Tabel 5. dapat dilihat bahwa seluruh koefisien dari setiap indikator variabel mempunyai nilai koefisien korelasi lebih besar dari 0,30 serta nilai sig lebih kecil dari 0,05 yang berarti bahwa seluruh indikator variabel dalam penelitian ini valid.

Tabel 6.

Hasil Uji Reliabilitas

\begin{tabular}{ccc}
\hline No & Variabel & Cronbach s Alpha \\
\hline 1 & Atmosfer Toko & 0,822 \\
2 & Emosi Positif & 0,813 \\
3 & Pembelian Tidak Terencana & 0,738 \\
\hline Sumber:
\end{tabular}

Sumber: Data Diolah, 2019 
Berdasarkan Tabel 6. dapat dilihat bahwa masing-masing instrumen penelitian yaitu atmosfer toko, emosi positif, dan pembelian tidak terencana mempunyai nilai Cronbach 's alpha lebih besar dari 0,60 yang berarti bahwa semua instrumen yang terdapat dalam penelitian ini reliabel sehingga dapat digunakan untuk melakukan penelitian.

Atmosfer toko dalam penelitian ini adalah variabel bebas $(\mathrm{X})$ yang diukur melalui 6 pernyataan yang berkaitan dengan atmosfer toko seperti pencahayaan, warna ruangan, suhu, aroma, tata letak barang, dan kebersihan. Berikut adalah jawaban rinci responden terhadap atmosfer toko Alfamart di Kota Denpasar.

Tabel 7.

Deskripsi Jawaban Responden Terhadap Atmosfer Toko

\begin{tabular}{|c|c|c|c|c|c|c|c|c|}
\hline \multirow{2}{*}{ No } & \multirow{2}{*}{ Pernyataan } & \multicolumn{5}{|c|}{ Jawaban } & \multirow{2}{*}{$\begin{array}{l}\text { Rata- } \\
\text { Rata }\end{array}$} & \multirow{2}{*}{ Kriteria } \\
\hline & & 1 & 2 & 3 & 4 & 5 & & \\
\hline 1 & $\begin{array}{l}\text { Gerai Alfamart mempunyai tingkat } \\
\text { pencahayaan yang baik. (X1) }\end{array}$ & 0 & 0 & 1 & 74 & 29 & 4,27 & $\begin{array}{l}\text { Sangat } \\
\text { Baik }\end{array}$ \\
\hline 2 & $\begin{array}{l}\text { Gerai Alfamart mempunyi warna } \\
\text { ruangan yang menarik. (X2) }\end{array}$ & 0 & 1 & 37 & 58 & 8 & 3,70 & Baik \\
\hline 3 & $\begin{array}{l}\text { Gerai Alfamart mempunyai pengaturan } \\
\text { suhu yang baik. (X3) }\end{array}$ & 0 & 2 & 13 & 73 & 16 & 3,99 & Baik \\
\hline 4 & $\begin{array}{l}\text { Gerai Alfamart mempunyai aroma } \\
\text { yang segar. (X4) }\end{array}$ & 0 & 1 & 40 & 56 & 7 & 3,66 & Baik \\
\hline 5 & $\begin{array}{l}\text { Gerai Alfamart mempunyai tata letak } \\
\text { barang yang baik. (X5) }\end{array}$ & 0 & 3 & 18 & 73 & 10 & 3,87 & Baik \\
\hline 6 & $\begin{array}{l}\text { Gerai Alfamart mempunyai tingkat } \\
\text { kebersihan yang tinggi. (X6) }\end{array}$ & 0 & 0 & 14 & 81 & 9 & 3,95 & Baik \\
\hline \multicolumn{7}{|c|}{ Rata-rata keseluruhan jawaban terhadap atmosfer toko } & 3,91 & Baik \\
\hline
\end{tabular}

Sumber: Data Diolah, 2019

Berdasarkan Tabel 7. dapat dilihat bahwa nilai rata-rata jawaban yang diberikan responden terhadap indikator pencahayaan adalah 4,27, warna ruangan sebesar 3,70, suhu sebesar 3,99, aroma sebesar 3,66, tata letak barang sebesar 3,87, dan kebersihan sebesar 3,95. Berdasarkan tanggapan responden tersebut, dapat diketahui bahwa variabel atmosfer toko secara keseluruhan dinilai baik dengan ratarata nilai berjumlah 3,91, bahkan pada indikator pencahayaan rata-rata responden memberikan nilai sangat baik yang juga sekaligus membuat indikator pencahyaan mendapat penilaian tertinggi dibandingkan indikator lain pada variabel atmosfer toko yaitu dengan nilai 4,27, sementara itu indikator aroma menjadi indikator dengan nilai terendah dengan nilai 3,66. Penilaian responden terhadap indikator lainnya pada variabel atmosfer toko ini berkisar antara 3,40-4,19 yang berarti bahwa indikator-indikator tersebut diberikan nilai baik oleh para responden.

Emosi positif dalam penelitian ini merupakan variabel mediasi (M) yang mana dalam penelitian ini emosi positif diukur menggunakan 4 pernyataan yang berkaitan dengan variabel emosi positif seperti perasaan nyaman, senang, puas, dan antusias. Berdasarkan Tabel 8. dapat dilihat bahwa nilai yang diberikan responden terhadap indikator rasa nyaman adalah 4,19 , rasa senang sebesar 3,93, rasa puas sebesar 3,89, dan rasa antusias sebesar 3,51. Berdasarkan penilaian yang telah diberkan responden, secara keseluruhan variabel emosi positif mendapatkan penilaian baik dengan nilai rata-rata berjumlah 3.88. Penilaian responden terhadap 
indikator-indikator pada variabel emosi positif mempunyai rentang nilai rata-rata 3.40 - 4.19 yang berarti bahwa responden memberikan nilai baik pada setiap indikator pada variabel emosi positif.

Tabel 8.

Deskripsi Jawaban Responden Terhadap Emosi Positif

\begin{tabular}{|c|c|c|c|c|c|c|c|c|}
\hline \multirow{2}{*}{ No } & \multirow{2}{*}{ Pernyataan } & \multicolumn{5}{|c|}{ Jawaban } & \multirow{2}{*}{$\begin{array}{l}\text { Rata- } \\
\text { Rata }\end{array}$} & \multirow{2}{*}{ Keterangan } \\
\hline & & 1 & 2 & 3 & 4 & 5 & & \\
\hline 1 & $\begin{array}{l}\text { Saya merasa nyaman ketika } \\
\text { berbelanja di Alfamart. (M1) }\end{array}$ & 0 & 0 & 6 & 72 & 26 & 4,19 & Baik \\
\hline 2 & $\begin{array}{l}\text { Saya merasa senang ketika } \\
\text { berbelanja di Alfamart. (M2) }\end{array}$ & 0 & 0 & 15 & 81 & 8 & 3,93 & Baik \\
\hline 3 & $\begin{array}{l}\text { Saya merasa puas ketika berbelanja } \\
\text { di Alfamart. (M3) }\end{array}$ & 0 & 0 & 23 & 69 & 12 & 3.89 & Baik \\
\hline 4 & $\begin{array}{l}\text { Saya merasa antusias ketika } \\
\text { berbelanja di Alfamart. (M4) }\end{array}$ & 0 & 6 & 47 & 43 & 8 & 3,51 & Baik \\
\hline \multicolumn{7}{|c|}{ Rata-rata keseluruhan jawaban terhadap emosi positif } & 3,88 & Baik \\
\hline
\end{tabular}

Pembelian tidak terencana pada penelitian ini merupakan variabel terikat (Y) yang diukur menggunakan 3 pernyataan yang berhubungan dengan pembelian tidak terencana seperti pembelian yang tanpa melalui proses perencanaan, pembelian yang dilakukan ketika melihat produk, dan pembelian yang dilakukan tanpa berpikir panjang. Berikut adalah hasil jawaban secara rinci dari para responden terkait dengan pembelian tidak terencana.

Tabel 9.

Deskripsi Jawaban Responden Terhadap Pembelian Tidak Terencana

\begin{tabular}{|c|c|c|c|c|c|c|c|c|}
\hline \multirow{2}{*}{ No } & \multirow{2}{*}{ Pernyataan } & \multicolumn{5}{|c|}{ Jawaban } & \multirow{2}{*}{$\begin{array}{l}\text { Rata- } \\
\text { Rata }\end{array}$} & \multirow{2}{*}{ Keterangan } \\
\hline & & 1 & 2 & 3 & 4 & 5 & & \\
\hline \multirow[b]{2}{*}{2} & $\begin{array}{l}\text { Saya pernah membeli produk di } \\
\text { Alfamart yang tidak saya } \\
\text { rencanakan sebelumnya. }\end{array}$ & 0 & 0 & 4 & 76 & 24 & 4,19 & Baik \\
\hline & $\begin{array}{l}\text { Saya pernah teringat sedang } \\
\text { membutuhkan suatu produk ketika } \\
\text { melihat produk tersebut di } \\
\text { Alfamart dan langsung } \\
\text { membelinya. }\end{array}$ & 0 & 1 & 5 & 67 & 31 & 4,23 & Sangat Baik \\
\hline 3 & $\begin{array}{l}\text { Saya pernah membeli produk di } \\
\text { Alfamart tanpa memikirkan akibat } \\
\text { negatif yang ditimbulkan dari } \\
\text { pembelian tersebut. }\end{array}$ & 0 & 6 & 37 & 48 & 13 & 3,65 & Baik \\
\hline & $\begin{array}{l}\text {-rata keseluruhan jawaban terhad } \\
\text { terencana }\end{array}$ & & & & da & & 4,02 & Baik \\
\hline
\end{tabular}

Sumber: Data Diolah, 2019

Berdasarkan Tabel 9. dapat diketahui bahwa nilai yang diberikan oleh para responden pada indikator pembelian yang dilakukan secara tidak terencana sebesar 4,19 , pembelian yang dilakukan karena melihat produk sebesar 4,23, dan pembelian yang dilakukan tanpa berpikir panjang sebesar 3,65. Berdasarkan data tersebut dapat diketahui juga bahwa indikator pembelian yang dilakukan karena melihat 
produk mendapatkan penilaian sangat baik dari para responden karena mendapat nilai 4,23, sementara itu untuk indikator pembelian yang dilakukan tanpa perencanaan dan indikator pembelian yang dilakukan tanpa berpikir panjang mendapatkan penilaian baik dengan rata-rata nilai masing-masing 4,19 dan 3,65. Secara keseluruhan, variabel pembelian tidak terencana mendapatkan penilaian baik oleh para responden dengan nilai rata-rata berjumlah 4,02.

Tabel 10.

Hasil Uji Normalitas Model Struktur 1

\begin{tabular}{cc}
\hline & Unstandardized Residual \\
\hline N & 104 \\
Kolmogorov Smirnov & 0.77 \\
Asymp Sig (2-tailed) & 0.147 \\
\hline Sumber: Data Diolah, 2019
\end{tabular}

Pada Tabel 10. dapat diketahui bahwa dari hasil uji normalitas pada model struktural 1 memperlihatkan hasil bahwa nilai Kolmogorov Smirnov adalah sebesar 0,77, sementara itu nilai Asymp Sig (2-tailed) adalah sebesar 0,147 yang berarti bahwa model persamaan regresi berdistribusi normal karena nilai Asymp Sig (2tailed) lebih besar dari ,.05.

Tabel 11.

Hasil Uji Normalitas Model Struktural 2

\begin{tabular}{cc}
\hline & Unstandardized Residual \\
\hline N & 100 \\
Kolmogorov Smirnov & 0.084 \\
Asymp Sig (2-tailed) & 0.068 \\
\hline
\end{tabular}

Sumber: Data Diolah, 2019

Pada Tabel 11. dapat diketahui bahwa dari hasil uji normalitas pada model struktural 2 menunjukkan hasil bahwa nilai Kolmogorov Smirnov adalah 0,084 sementara nilai Asymp Sig (2-tailed) adalah 0,068, karena nilai Asymp Sig (2-tailed) lebih besar dari 0.05 berarti dapat dikatakan bahwa model persamaan regresi berdistribusi normal.

Tabel 12.

Hasil Uji Multikolinieritas Model Struktural 1

\begin{tabular}{ccc}
\hline Model & \multicolumn{2}{c}{ Collinierity Statistic } \\
& Tolerance & VIF \\
\hline Atmosfer Toko & 1.00 & 1.00 \\
\hline Sumber: Data Diolah, 2019 & \multicolumn{2}{c}{}
\end{tabular}

Pada Tabel 12. dapat dilihat bahwa nilai tolerance untuk variabel atmosfer toko adalah sebesar 1.00 di mana nilai ini lebih besar dari 0,10 , sementara itu nilai VIF untuk variabel atmosfer toko juga sebesar 1,00 di mana nilai ini lebih kecil dari 10, sehingga dapat dikatakan bahwa pada model regresi ini tidak terjadi gejala multikolinieritas sehingga model ini layak untuk digunakan. 
Tabel 13.

Hasil Uji Multikolinieritas Model Struktural 2

\begin{tabular}{ccc}
\hline Model & \multicolumn{2}{c}{ Collinierity Statistic } \\
& Tolerance & VIF \\
\hline Atmosfer Toko & 0,348 & 2,874 \\
Emosi Positif & 0,348 & 2,874 \\
\hline
\end{tabular}

Sumber: Data Diolah, 2019

Pada Tabel 13. dapat dilihat bahwa nilai tolerance untuk masing-masing variabel atmosfer toko dan emosi positif adalah sebesar 0,348 di mana nilai ini lebih besar daripada 0,10 , sementara itu nilai VIF untuk masing-masing variabel atmosfer toko dan emosi positif adalah sebesar 2,875 di mana nilai ini lebih kecil dari 10 . Berdasarkan hal tersebut maka dapat dikatakan bahwa pada model regresi ini tidak terdapat gejala multikolinieritas yang berarti model ini layak untuk digunakan.

Tabel 14.

Hasil Uji Heteroskedastisitas Model Persamaan 1

\begin{tabular}{cc}
\hline Model & Sig. \\
\hline Atmosfer Toko & 0,764 \\
\hline
\end{tabular}

Sumber: Data Diolah, 2019

Pada Tabel 14. menunjukkan hasil bahwa nilai signifikansi pada model persamaan 1 untuk variabel atmosfer toko adalah sebesar 0,764 di mana nilai ini lebih besar dari 0,05 yang berarti bahwa pada model persamaan 1 ini tidak terdapat gejala heteroskedastisitas.

Tabel 15.

Hasil Uji Heteroskedastisitas Model Persamaan 2

\begin{tabular}{cc}
\hline Model & Sig. \\
\hline Atmosfer Toko & 0,092 \\
Emosi Positif & 0,077 \\
\hline
\end{tabular}

Sumber: Data Diolah, 2019

Pada Tabel 15. menunjukkan hasil bahwa nilai signifikansi untuk variabel atmosfer toko adalah sebesar 0,092 dan nilai signifikansi untuk variabel emosi positif adalah sebesar 0,077 di mana nilai ini lebih besar dari 0,05, sehingga dapat dikatakan bahwa pada model ini tidak terdapat gejala heteroskedastisitas.

Tabel 16.

Hasil Anlisis Jalur Model 1

\begin{tabular}{|c|c|c|c|c|c|}
\hline \multirow[t]{2}{*}{ Variabel } & \multicolumn{2}{|c|}{$\begin{array}{c}\text { Unstandardized } \\
\text { Coefficients }\end{array}$} & \multirow{2}{*}{$\begin{array}{c}\text { Standardized } \\
\text { Coefficients } \\
\text { Beta } \\
\end{array}$} & \multirow[t]{2}{*}{ t hitung } & \multirow[t]{2}{*}{$\begin{array}{l}\text { Sig. } \\
\text { uji t }\end{array}$} \\
\hline & B & Std.Error & & & \\
\hline (Constant) & 0,368 & 1,102 & & 0,334 & 0,739 \\
\hline Atmosfer Toko (X) & 0,647 & 0,047 & 0,808 & 13,826 & 0,000 \\
\hline R Square & 0,652 & & & & \\
\hline F Statistik & 191,157 & & & & \\
\hline Signifikansi Uji F & 0,000 & & & & \\
\hline
\end{tabular}


Tabel 17.

Hasil Anlisis Jalur Model 2

\begin{tabular}{lccccc}
\hline \multirow{2}{*}{ Variabel } & \multicolumn{2}{c}{$\begin{array}{c}\text { Unstandardized } \\
\text { Coefficients }\end{array}$} & $\begin{array}{c}\text { Standardized } \\
\text { Coefficients }\end{array}$ & t hitung & $\begin{array}{c}\text { Sig. } \\
\text { uji t }\end{array}$ \\
\cline { 2 - 4 } & $\mathbf{B}$ & $\begin{array}{c}\text { Std. } \\
\text { Error }\end{array}$ & Beta & & \\
\hline (Constant) & 0,529 & 0,893 & & 0,592 & 0,555 \\
Atmosfer Toko (X) & 0,291 & 0,064 & 0,458 & 4,532 & 0.000 \\
Emosi Positif (M) & 0,304 & 0,080 & 0,383 & 3,792 & 0.000 \\
R Square & 0.641 & & & & \\
F Statistik & 90,059 & & & & \\
Signifikansi Uji F & 0.000 & & & & \\
\hline Sumber: Data Diolah, 2019 & & & &
\end{tabular}

Total nilai koefisien determinasi pada penelitian ini adalah 0,875 yang berarti bahwa sebesar $87,5 \%$ variasi pembelian tidak terencana dipengaruhi oleh atmosfer toko dan emosi positif sementara $12,5 \%$ sisanya dipengaruhi oleh faktor lain yang tidak dimasukan ke dalam model. Berdasarkan pengujian yang telah dilakukan pada penelitian ini diperoleh tingkat signifikansi $\mathrm{F}$ adalah sebesar 0,000 di mana nilai ini lebih kecil daripada 0,05 sehingga dapat dikatakan bahwa atmosfer toko dan emosi positif mempunyai pengaruh secara simultan terhadap pembelian tidak terencana

Berdasarkan pengujian yang dilakukan pada atmosfer toko terhadap emosi positif diperoleh hasil bahwa nilai signifikansi t adalah sebesar 0,000 dengan nilai beta adalah sebesar 0,808 . Nilai signifikansi t yang sebesar 0,000 bernilai lebih kecil dari 0,05 maka hal ini berarti $\mathrm{H}_{0}$ ditolak dan sementara itu $\mathrm{H}_{1}$ diterima sehingga hal ini menandakan bahwa atmosfer toko berpengaruh positif dan signifikan terhadap emosi positif. Berdasarkan pengujian yang telah dilakukan pada atmosfer toko terhadap pembelian tidak terencana didapatkan hasil bahwa nilai signifikansi $\mathrm{t}$ adalah sebesar 0,000 dengan nilai beta sebesar 0,458, dengan nilai signifikansi $t$ yang lebih kecil dari 0,05 maka dapat dikatakan bahwa $\mathrm{H}_{0}$ ditolak dan sementara itu $\mathrm{H}_{2}$ diterima yang berarti bahwa atmosfer toko berpengaruh positif dan signifikan terhadap pembelian tidak terencana. Berdasarkan pengujian yang telah dilakukan pada variabel emosi positif terhadap variabel pembelian tidak terencana diperoleh hasil bahwa nilai signifikansi t adalah sebesar 0,000 dengan nilai beta sebesar 0,383, dengan nilai signifikansi t yang lebih kecil dari 0,05 maka dapat dikatakan bahwa $\mathrm{H}_{0}$ ditolak dan sementara itu $\mathrm{H}_{3}$ diterima dengan demikian hal ini berarti bahwa emosi positif berpengaruh positif dan signifikan terhadap pembelian tidak terencana.

Tabel 18.

Pengaruh Langsung dan Tidak Langsung Variabel Atmosfer Toko(X), Emosi Positif(M), dan Pembelian Tidak terencana (Y)

\begin{tabular}{cccc}
\hline Pengaruh Variabel & Pengaruh Langsung & $\begin{array}{c}\text { Pengaruh Tidak } \\
\text { Langsung } \\
\left(\boldsymbol{\beta}_{\mathbf{1}} \mathbf{x} \boldsymbol{\beta} \mathbf{3}\right)\end{array}$ & Pengaruh Total \\
\hline $\mathrm{X} \rightarrow \mathrm{M}$ & 0,808 & & 0,808 \\
$\mathrm{X} \rightarrow \mathrm{Y}$ & 0,458 & 0,309 & 0.767 \\
$\mathrm{M} \rightarrow \mathrm{Y}$ & 0,383 & & 0,383 \\
\hline
\end{tabular}

Sumber: Data Diolah, 2019 
Berdasarkan Tabel 18. dapat dilihat pengaruh langsung antar variabel yaitu pengaruh atmosfer toko terhadap emosi positif yang mempunyai nilai koefisien beta sebesar 0,808 , pengaruh atmosfer toko terhadap pembelian tidak terencana yang mempunyai koefisien beta sebesar 0,458, dan pengaruh emosi positif terhadap pembelian tidak terencana yang mempunyai koefisien beta sebesar 0,383. Sementara pada pengaruh tidak langsung antara atmosfer toko terhadap pembelian tidak terencana yang dimediasi oleh variabel emosi positif mempunyai nilai koefisien beta sebesar 0,309. Hal ini membuktikan bahwa emosi positif mampu memediasi pengaruh atmosfer toko terhadap pembelian tidak terencana dengan total pengaruh sebesar 0,767. Berdasarkan hasil perhitungan di atas dapat diketahui bahwa nilai $t$ hitung adalah sebesar 3,65 di mana nilai ini lebih besar dari pada $t$ tabel dengan tingkat signifikansi 0,05 yaitu $1,98(3,65>1,98)$, dengan demikian hal ini berarti $\mathrm{H}_{0}$ di tolak dan $\mathrm{H}_{1}$ diterima sehingga dapat dikatakan bahwa emosi positif dapat memediasi pengaruh atmosfer toko terhadap pembelian tidak terencana.

Hasil uji hipotesis pada pengaruh atmosfer toko terhadap emosi positif menunjukkan hasil bahwa atmosfer toko mempunyai pengaruh yang positif dan signifikan terhadap emosi positif. Hal ini berarti semakin baik pengaturan suhu, aroma, pencahayaan dan warna ruangan pada gerai Alfamart, maka akan menimbulkan rasa senang, puas, antusias dan nyaman pada diri konsumen Alfamart, begitu juga sebaliknya semakin buruk pengaturan suhu, aroma, pencahayaan dan warna ruangan pada gerai Alfamart, maka hal tersebut akan menimbulkan rasa kecewa, marah, benci, dan sedih pada diri konsumen Alfamart. Pada penelitian ini variabel atmosfer toko diukur menggunakan beberapa indikator yaitu pencahayaan, warna ruangan, suhu, aroma, layout, dan kebersihan. Berdasarkan hasil jawaban dari responden, indikator pencahayaan mendapatkan nilai tertinggi dari semua indikator yang digunakan untuk mengukur variabel atmosfer toko. Hal ini mengindikasikan bahwa emosi positif dari konsumen Alfamart sering kali timbul melalui pencahayaan toko yang baik.

Hasil penelitian ini mendukung penelitian-penelitian sebelumnya yang dilakukan oleh Dewi \& Giantari (2015), Dharma \& Kusumadewi (2018), Madjid (2015), Murnawati \& Khairani (2018), Tulipa et al. (2015) yang juga menyatakan bahwa atmosfer toko mempunyai pengaruh yang positif dan signifikan terhadap emosi positif, selain itu penelitian-penelitian sebelumnya juga mempunyai kesamaan dalam penelitian ini, seperti lokasi penelitian di mana antara penelitian ini dan penelitian-penelitian sebelumnya sama-sama dilakukan di Kota Denpasar. Metode yang digunakan juga sama mulai dari metode penentuan sampel, pengumpulan data hingga teknik analisis data yang digunakan, selain itu terdapat juga kesamaan pada sebagian besar indikator penelitian yang digunakan.

Pembelian tak terencana merupakan jenis pembelian yang tidak direncanakan sebelumnya yang diputuskan secara seketika tanpa memikirkan sebab akibat dari pembelian tersebut. Hasil uji hipotesis pada pengaruh atmosfer toko terhadap pembelian tidak terencana menunjukkan hasil bahwa atmosfer toko berpengaruh positif dan signifikan terhadap pembelian tidak terencana. Hal ini berarti semakin baik pengaturan suhu, aroma, pencahayaan dan warna ruangan pada gerai Alfamart, maka akan meningkatkan kemungkinan pembelian yang dilakukan secara tidak terencana oleh konsumen Alfamart, begitu juga sebaliknya semakin buruk 
pengaturan suhu, aroma, pencahayaan dan warna ruangan pada gerai Alfamart, maka akan membuat konsumen tidak betah berada di dalam gerai sehingga akan memperkecil kemungkinan terjadinya pembelian tidak terencana oleh konsumen Alfamart. Pada penelitian ini variabel atmosfer toko diukur menggunakan beberapa indikator yaitu pencahayaan, warna ruangan, suhu, aroma, layout, dan kebersihan. Berdasarkan hasil penilaian responden pada variabel atmosfer toko, indikator pencahayaan mendapat nilai tertinggi dari semua indikator yang digunakan untuk mengukur variabel atmosfer toko. Hal ini mengindikasikan bahwa pembelian tidak terencana yang dilakukan oleh konsumen Alfamart sering kali disebabkan oleh pencahayaan gerai Alfamart yang baik, karena dengan pencahayaan yang baik akan membuat konsumen Alfamart akan betah berada di dalam gerai.

Hasil dari penelitian ini mendukung penelitian-penelitian sebelumnya yang dilakukan Utami \& Rastini (2015), Pemayun \& Ekawati (2016), Setiawati \& Sukawati (2017), Jaya \& Suparna (2018), Temaja et al. (2015), Akram et al. (2016), Nandha et al. (2017), Widyastuti (2018), (Ukpabi 2015) yang sama-sama menyatakan bahwa atmosfer toko mempunyai pengaruh positif dan signifikan terhadap pembelian tidak terencana, selain itu antara penelitian-penelitian sebelumnya dan penelitian ini juga dapat ditemukan kesamaan karakteristik responden, seperti jumlah responden perempuan yang lebih banyak dibandingkan dengan jumlah responden laki-laki, mayoritas responden yang berusia 30 tahun ke bawah, pendidikan terakhir responden SMA/sederajat, serta pekerjaan mayoritas responden sebagai pelajar/mahasiswa.

Hasil uji hipotesis pada pengaruh emosi positif terhadap pembelian tidak terencana menunjukkan hasil bahwa emosi positif mempunyai pengaruh yang positif dan signifikan terhadap pembelian tidak terencana. Hal ini berarti jika konsumen Alfamart merasa senang, puas, antusias, dan nyaman ketika berada di dalam gerai, maka akan meningkatkan pembelian yang dilakukan secara tidak terencana oleh konsumen Alfamart, begitu juga sebaliknya jika konsumen Alfamart merasa sedih, marah, benci, dan kecewa ketika berada di dalam gerai, maka hal ini akan memperkecil kemungkinan terjadinya pembelian yang dilakukan secara tidak terencana oleh konsumen Alfamart. Pada penelitian ini variabel emosi positif diukur menggunakan beberapa indikator, yaitu rasa nyaman, senang, puas, dan antusias. Berdasarkan penilaian yang diberikan responden, indikator rasa nyaman memiliki penilaian yang paling tinggi dibandingkan indkator lainnya yang digunakan untuk mengukur variabel emosi positif. Hal ini mengindikasikan bahwa pembelian tidak terencana yang dilakukan oleh konsumen Alfamart sering kali terjadi karena rasa nyaman yang dimiliki oleh konsumen Alfamart.

Hasil penelitian ini mendukung penelitian-penelitian sebelumnya yang dilakukan oleh Budiharta \& Santika (2015), Darmayasa \& Sukaatmadja (2017) serta Kinasih \& Jatra (2018) Diah et al. (2019) yang juga menyatakan bahwa emosi positif berpengaruh positif dan signifikan terhadap pembelian tidak terencana, selain itu penelitian-penelitian sebelumnya juga mempunyai kesamaan dengan penelitian ini. Kesamaan yang paling terlihat adalah karakteristik responden, di mana kebanyakan responden adalah perempuan, berusia di bawah 30 tahun, Pendidikan terkahir SMA/sederajat, dan merupakan pelajar/mahasiswa. Penelitian 
ini juga memiliki kesamaan pada sebagian besar indikator yang digunakan untuk mengukur variabel.

Hasil uji hipotesis pada peran emsoi positif dalam memediasi pengaruh atmosfer toko terhadap pembelian tidak terencana menunjukkan hasil bahwa emosi positif dapat memediasi pengaruh atmosfer toko terhadap pembelian tidak terencana. Hal ini berarti bahwa semakin baik pengaturan suhu, aroma, pencahayaan dan warna ruangan yang ada pada gerai Alfamart, maka akan membuat konsumen Alfamart merasa senang, puas, antusias, dan nyaman berada di dalam gerai Alfamart, di mana hal tersebut akan membuat konsumen betah berlama-lama berada di dalam gerai sehingga dapat meningkatkan kemungkinan terjadinya pembelian yang dilakukan secara tidak terencana oleh konsumen Alfamart, begitu juga sebaliknya jika pengaturan suhu, aroma, pencahayaan dan warna ruangan pada gerai Alfamart semakin buruk, maka akan membuat konsumen Alfamart merasa sedih, marah, benci, dan kecewa ketika berada di dalam gerai, di mana hal ini akan memperkecil kemungkinan pembelian yang dilakukan secara tidak terencana oleh konsumen Alfamart. Berdasarkan penelitian ini, dapat diketahui bahwa indikator pencahayaan pada variabel atmosfer toko dan indikator rasa nyaman pada variabel emosi positif mendapat penilaian tertinggi dari para responden. Hal ini mengindikasikan bahwa pencahayaan toko yang baik sering kali menimbulkan rasa nyaman pada diri konsumen, di mana rasa nyaman ini akan dapat membuat konsumen melakukan pembelian secara tidak terencana pada gerai Alfamart.

Hasil penelitian ini mendukung penelitian-penelitian sebelumnya yang dilakukan oleh Dewi \& Giantari (2015), Dharma \& Kusumadewi (2018) serta Budiharta \& Santika (2015), Bilal Ahmad et al. (2019) yang juga menyatakan bahwa emosi positif mampu memediasi pengaruh atmosfer toko terhadap pembelian tidak terencana, selain itu antara penelitian-penelitian sebelumnya dan penelitian ini juga mempunyai kesamaan. Kesamaan tersebut terletak pada lokasi penelitian yang sama-sama dilakukan di Kota Denpasar. Pada karakteristik responden juga terdapat kesamaan, yaitu mayoritas responden adalah perempuan, berusia dibawah 30 tahun, Pendidikan terakhir SMA/sederajat, dan merupakan pelajar/mahasiswa.

Variabel-variabel yang mempunyai hubungan dengan pembelian tidak terencana dalam penelitian ini adalah atmosfer toko dan emosi positif. Implikasi teoritis yang berhubungan dengan pembelian tidak terencana telah konsisten menguatkan teori sebelumnya bahwa atmosfer toko dan emosi positif dapat mendorong konsumen untuk melakukan pembelian secara tidak terencana pada gerai Alfamart. Variabel emosi positif juga mampu memediasi atmosfer toko dengan pembelian tidak terencana. Semakin baik pengaturan suasana atau atmosfer toko pada gerai Alfamart, maka akan dapat meningkatkan emosi positif pada setiap konsumennya di mana dengan meningkatnya emosi positif pada benak konsumen Alfamart akan mengakibatkan meningkatnya pembelian yang dilakukan secara tidak terencana yang dilakukan oleh konsumen Alfamart. Hal ini tentunya memperjelas hubungan yang ada antara variabel yang terdapat pada penelitian ini yaitu atmosfer toko, emosi positif dan pembelian tidak terencana serta mendukung penelitian-penelitian sebelumnya yang telah disajikan pada hipotesis penelitian 
Hasil penelitian ini diharapkan dapat menjadi masukan bagi pihak Alfamart untuk dapat meningkatkan potensi pembelian yang dilakukan secara tidak terencana oleh konsumennya dengan lebih memperhatikan kondisi atmosfer toko, karena berdasarkan hasil penelitian ini menunjukkan bahwa atmosfer toko Alfamart mempunyai pengaruh positif dan signifikan terhadap terciptanya emosi positif terhadap konsumennya di mana dengan terciptanya emosi positif dari para konsumen akan meningkatkan potensi pembelian tidak terencana yang dilakukan oleh konsumen Alfamart. Atmosfer toko Alfamart juga mempunyai pengaruh langsung terhadap pembelian tidak terencana yang dilakukan oleh konsumen Alfamart yang berarti jika pihak Alfamart dapat mengatur atmosfer toko dengan baik akan langsung mampu meningkatkan pembelian tidak terencana yang dilakukan oleh konsumennya.

\section{SIMPULAN}

Variabel atmosfer toko dan emosi positif secara umum berpengaruh positif dan signifikan terhadap perilaku pembelian tidak terencana pada konsumen Alfamart di Kota Denpasar. Sementara itu variabel emosi positif juga mampu memediasi pengaruh atmosfer toko terhadap pembelian tidak terencana pada konsumen Alfamart di Kota Denpasar. Atmosfer toko mempunyai pengaruh positif dan signifikan terhadap emosi positif, hal ini berarti jika Alfamart mampu menghadirkan suasana atau atmosfer toko yang baik, maka hal tersebut akan meningkatkan emosi positif pada konsumen Alfamart di Kota Denpasar.

Atmosfer toko mempunyai pengaruh positif dan signifikan terhadap pembelian tidak terencana, hal ini berarti jika Alfamart di Kota Denpasar mampu menghadirkan suasana atau atmosfer toko yang baik, maka akan membuat meningkatnya pembelian tidak terencana yang dilakukan oleh konsumen Alfamart di Kota Denpasar. Emosi positif mempunyai pengaruh positif dan signifikan terhadap pembelian tidak terencana, hal ini berarti jika konsumen Alfamart di Kota Denpasar mempunyai emosi positif yang tinggi, maka akan meningkatkan pembelian tidak terencana pada konsumen Alfamart di Kota Denpasar. Emosi positif mampu memediasi pengaruh atmosfer toko terhadap pembelian tidak terencana, hal ini berarti jika Alfamart di Kota Denpasar mampu menghadirkan atmosfer toko yang baik, maka akan membuat meningkatnya emosi positif pada konsumen Alfamart di Kota Denpasar, dengan meningkatnya emosi positif pada konsumen Alfamart di Kota Denpasar maka akan meningkatkan pembelian tidak terencana pada konsumen Alfamart di Kota Denpasar.

Bagi pihak manajemen Alfamart khususnya yang berada di Kota Denpasar, sebaiknya lebih memperhatikan lagi terkait atmosfer atau suasana toko yang terdapat di setiap gerai Alfamart yang berada di wilayah Kota Denpasar, terutama pada pengaturan aroma gerai dengan menambahkan wewangian atau pengharum ruangan di dalam gerai, karena berdasarkan penelitian ini aroma gerai mempunyai nilai yang paling rendah pada variabel atmosfer toko. Pada penelitian ini dapat diketahui bahwa rasa antusias konsumen dalam berbelanja merupakan mempunyai nilai yang paling rendah pada variabel emosi positif, oleh karena itu sebaiknya pihak manajemen Alfamart dapat meningkatkan rasa antusias konsumen dalam 
berbelanja dengan cara memberikan potongan harga yang menarik, menghadirkan produk-produk terbaru, pemberian hadiah pada konsumen dan lain sebagainya. Pada penelitian ini dapat diketahui bahwa sebelum melakukan perbelanjaan konsumen sering kali berpikir panjang terlebih dahulu, oleh sebab itu sebaiknya manajemen Alfamart dapat membuat tampilan produk yang semenarik mungkin agar konsumen dapat melakukan pembelian tanpa berpikir panjang atau spontan. Bagi peneliti selanjutnya diharapkan dapat memperluas cakupan penelitian dengan menggunakan berbagai macam variabel lain yang diduga mempunyai pengaruh terhadap pembelian tidak terencana atau impulse buying ini, seperti potongan harga, promosi, kualitas produk, merchandise, harga, dan lain sebagainya.

\section{REFERENSI}

Ahad, Nouman, Nazish Tanveer, Ali Tanzila, dan Zoya Khanum. 2015. "Impulse Buying Behavior and its Influential Factors." Scholars Journal of Economics, Business and Management 2(7A):703-6.

Akram, Umair, Peng Hui, Muhammad Kaleem Khan, Muhammad Hashim, dan Shahid Rasheed. 2016. "Impact of Store Atmosphere on Impulse Buying Behaviour: Moderating Effect of Demographic Variables." International Journal of $u$ - and e-Service, Science and Technology 9(7):43-60.

Amiri, Farhad, Jalal Jasour, Shir Pour, dan Alized Mohsen. 2015. "Evaluation of effective fashionism involment factors effects on Impulse Buying of customer and condition of interrelation between these factors." Journal of basic and applied scientific research 2(2):1-9.

Bilal Ahmad, Muhammad, Hafiz Fawad Ali, Maha Sabir Malik, Asad Afzal Humayun, dan Sana Ahmad. 2019. "Factors Affecting Impulsive Buying Behavior with Mediating role of Positive Mood: An Empirical Study." European Online Journal of Natural and Social Sciences 8(1):17-35.

Budiharta, Kadek dan I. Wayan Santika. 2015. "Peran Emosi Positif Sebagai Pemediasi Pengaruh Stimulus Toko Terhadap Impulse Buying Pakaian Di Matahari Department Store Kuta Square." E-Jurnal Manajemen Unud 4(3):457-73.

Darmayasa, Ni Made Intan Agustina Ariani dan I. Putu Gde Sukaatmadja. 2017. "Analisis Pengaruh Store Atmosphere Dan Sales Promotion Terhadap Emotional Shopping Dan Impulse Buying Behavior." E-Journal Manajemen Unud 6(11):6061-89.

Dewi, K. T. dan GAK Giantari. 2015. "Peran Emosi Positif Dalam Memediasi Store Atmosphere Terhadap Pembelian Impulsif (Studi Pada Konsumen Matahari Department Store Duta Plaza Denpasar).” E-Journal Manajemen Unud 4(12):4419-48. 
Dharma, Putu Gde Krisnandadifa dan Ni Made Wulandari Kusumadewi. 2018. "Peran Emosi Memediasi Pengaruh Store Atmosphere Terhadap Perilaku Pembelian di Karakter Kopi." E-Jurnal Manajemen Unud 7(12):6815 - 6841.

Diah, Ahyar Muhammad, Heldina Pristanti, Reni Aspianti, dan - Syachrul. 2019. "The Influence of Hedonic Shopping Value and Store Atmosphere and Promotion of Impulse Buying through Positive Emotion on the consumer of Sogo Department Store in Samarinda." Advances in Economics, Business and Management Research 75(1):103-8.

Fam, Kim-Shyan, Bill. Merriless, James E. Richard, Laszlo Jozsa, Yongqiang Li, dan Jayne Krisjanous. 2015. "In-store marketing: a strategic perspective." Asia Pacific Journal of Marketing and Logistic 23(2):165-76.

Helmefalk, Miralem dan Breatll Hulten. 2017. "Multi-sensory congruent cues in designing retail store atmosphere: Effects on shoppers' emotions and purchase behavior." Journal of Retailing and Consumer Services 38(1):1-11.

Hussain, Riaz dan Mazhar Ali. 2015. "Effect Of Store Atmosphere On Consumer Purchese Intention.” International Journal Of Marketing Studies 7(2):35-43.

Jaya, Handy Surya dan Gede Suparna. 2018. "Pengaruh Atmosfer Toko, Kesesuaian Harga Terhadap Keputusan Pembelian Konsumen Pada Temday Store Denpasar.” E-Jurnal Manajemen Unud 7(6):1887-2912.

Khorrami, Maryam Sarikhani dan Mohammad Rahim Esfidani. 2015. "The Effect of Situational Factors on Impulse Buying and Compulsive Buying: Clothing." International Journal of Managemen 2(8):823-37.

Kinasih, Ida Ayu Diksita dan I. Made Jatra. 2018. "Peran Emosi Positif Memediasi Pengaruh Fashion Involvement Dan Hedonic Consumption Tendency Terhadap Impulse Buying." E-Jurnal Manajemen Unud 7(6):3258-90.

Madjid, Rahmat. 2015. "The Influence Store Atmosphere Towards Customer Emotions and Purchase Decisions." International Journal of Humanities and Social Science Invention 3(10):11-19.

Murnawati dan Zulia Khairani. 2018. "Store Environmental Atmosphere on Giant Hypermarket Pekanbaru: Do Effect on Consumers Positive Emotion and Impulse?" IOP Conference Series: Earth and Environmental Science 175(1):7.

Nandha, Octaprinanta, Kusumawati Andriani, dan Pangestuti Edriana. 2017. "Hedonic Consumption Tendency on Emotional States and Its Impact." Rjoas 3(63):72-78. 
Negara, A. A. Bagus Jambe dan Ni Made Wulandari Kusumadewi. 2018. "Pengaruh Atmosfer Ritel Dan Promosi Terhadap Impulse Buying Yang Dimediasi Emosi Positif." E-Jurnal Manajemen Unud 7(7):3944-73.

Pemayun, Tjokorda Istri Dwi Pradnyawati dan Ni Wayan Ekawati. 2016. "Pengaruh Promosi, Atmosfer Gerai, Dan Merchandise Terhadap Pembelian Impulsif Pada Hardy's Mall Gatsu Denpasar." E-Jurnal Manajemen Unud 5(7):4132 - 4160 .

Setiawati, A. A. Diah dan Tjok. Gde Raka Sukawati. 2017. "Pengaruh Merchandise Dan Atmosfer Gerai Terhadap Nilai Hedonik Dan Perilaku Pembelian Impulsif Di Lippo Mall Kuta.” E-Jurnal Manajemen Unud 6(9):5205-31.

Temaja, I. Km. Wisnu Bayu, Gede Bayu Rahanata, dan Ni Nyoman Kerti Yasa. 2015. "Pengaruh Fashion Involvement, Atmosfer Toko Dan Promosi Penjualan Terhadap Impulse Buying Pada Matahari Department Store Di Kota Denpasar." E-Jurnal Manajemen Unud 4(6):1466-82.

Tulipa, Diyah, Sri Gunawan, dan V. Henky Supit. 2015. "The Influence of Store Atmosphere on Emotional Responses and Re-Purchase Intentions." Business Management and Strategy 5(2):151.

Ukpabi, Dandison. 2015. "Store Atmosphere and Impulse Buying: an Empirical Study of Shoppers in Port Harcourt." The International Academic Conference for Sub-Sahara African Transformation \& Development 2015 3(March 2015):1-13.

Utami, Okky Ratna dan Ni Made Rastini. 2015. "Pengaruh Variabel Demografi, Kualitas Layanan, Atmosfer Toko Pada Impulse Buying Di Hypermart Mal.” E-Jurnal Manajemen Unud 4(6):1229-37.

Widyastuti, Pristiana. 2018. "Does visual merchandising, store atmosphere and private label product influence impulse buying? Evidence in Jakarta." Journal of Business and Retail Management Research 12(3):140-48. 